This is the peer reviewed version of the following article:

Andrea Monti \& Walter Zegada-Lizarazu

Sixteen-Year Biomass Yield and Soil Carbon Storage of Giant Reed (Arundo donax L.) Grown Under Variable Nitrogen Fertilization Rates

BioEnergy Research volume 9, pages 248-256 (2016)

which has been published in final form at

https://doi.org/10.1007/s12155-015-9685-z

This article may be used for non-commercial purposes in accordance with Wiley Terms and Conditions for Use of Self-Archived Versions. 


\section{Sixteen-Year Biomass Yield and Soil Carbon Storage of Giant Reed (Arundo donax L.) Grown Under Variable Nitrogen Fertilization Rates}

Andrea Monti 1

Walter Zegada-Lizarazu $1{ }^{*}$

Phone +390512096665

Emailwalter.zegadalizarazu@unibo.it

Emaila.monti@unibo.it

1 Department of Agricultural Sciences, University of Bologna, Viale G.

Fanin, 44-40127 Bologna, Italy

\section{Abstract}

High and stable biomass yields for long periods (15-20 years) are indispensable for the successful establishment of a well-developed bioenergy sector. However, the effects of management practices, particularly nitrogen fertilization, on productivity and soil organic carbon (SOC) are difficult to understand, especially when considering that continuous harvesting cycles may have cumulative effects on the crop and its resources use capacity. The objective of this study was to evaluate the effects of different $\mathrm{N}$ fertilization levels on biomass production and SOC accumulation of giant reed over 16 years. Every year, starting from the second one, two $\mathrm{N}$ fertilization rates were applied: $80\left(\mathrm{~N}_{80}\right)$ and $160\left(\mathrm{~N}_{160}\right)$ $\mathrm{kg} \mathrm{N} \mathrm{ha}{ }^{-1}$. The control treatment $\left(\mathrm{N}_{0}\right)$ was unfertilized. Nitrogen content and use capacity, and SOC gains were determined. Mean 16-year biomass yields were $16.2,17.1$, and $19.5 \mathrm{Mg} \mathrm{ha}^{-1}$ in the $\mathrm{N}_{0}, \mathrm{~N}_{80}$, and $\mathrm{N}_{160}$ treatments, respectively. Variable yielding phases were observed in the $\mathrm{N}_{160}$ treatment with declining yields towards the last sampling season, whereas the $\mathrm{N}_{0}$ was characterized by increasing yields up to the fourth growing season; thereafter, declining yields were observed. Nitrogen concentration and removed $\mathrm{N}$ in the aboveground harvested biomass increased from $\mathrm{N}_{0}$ to $\mathrm{N}_{160}$ and as the stand become older. Mean total SOC stock gains were 1.0 
and 0.6 $\mathrm{Mg} \mathrm{C} \mathrm{ha}{ }^{-1}$ year ${ }^{-1}$ in the $\mathrm{N}_{160}$ and $\mathrm{N}_{0}$ treatments, respectively. The largest SOC stocks were found in the topsoil, with the largest amount (12 $\mathrm{Mg} \mathrm{C} \mathrm{ha}{ }^{-1}$ in 16 years) in the $\mathrm{N}_{160}$ treatment. In conclusion, long-term high $\mathrm{N}$ fertilization rates result in marginal increments in biomass productivity (about $3 \mathrm{Mg} \mathrm{ha}^{-1}$ year $^{-1}$ ), but in substantial increments in SOC, especially in surface soil layers. A farmer might prefer to grow giant reed without the burdens of fertilization despite the seemingly benefits on SOC and lower yields of unfertilized plots.

\section{Keywords}

Bioenergy

Biomass

Marginal land

Long-term

Soil carbon

Yield

Andrea Monti and Walter Zegada-Lizarazu contributed equally to this work.

\section{Introduction}

The production of giant reed (Arundo donax L.) as a potential energy feedstock is increasingly attracting the interest of relevant private and public sectors in EU, especially under Mediterranean climates. This is mainly because of its high biomass yielding potential, adaptability to marginal lands, and desirable agronomic characteristics to supply sustainable and renewable energy sources to comply with current environmental concerns, international climate change agreements, and bioenergy policies. During the last 20 or 30 years, several studies have been carried out to evaluate the potential productivity of perennial grasses, such as giant reed, under different environments and management practices [1-7]. However, most of these studies refer to a limited period of giant reed stand lifespan, while the long-term effects of different management practices, such as fertilization on productivity or on carbon storage, have not been thoroughly evaluated.

It is speculated that the economic productive lifetime of giant reed could last about 10 years [ $3-5$ ], but its high establishment costs, either by rhizomes or by in vitro propagated plants, determine that the stand remains productive for as many years as possible without depleting the soil resources or ecological 
services. Therefore, regardless of its intrinsic characteristic capacity to store and recycle nutrients in the rhizomes [8-10] which often act as an important variable in conditioning fertilization requirements, it is imperative to understand the most appropriate fertilization management practices to successfully grow giant reed for long periods. Such situation might be even more preponderant in marginal or less productive and fragile lands, which are identified as the most suitable ones to produce biomass crops while avoiding displacement of activities and/or land-use competition issues. In any case, even in more productive lands, growing giant reed without supplemental fertilization at some point of its productive lifetime may not be profitable. However, unjustified high fertilization levels, as in any other crop, besides being uneconomical, it has the potential to threaten the surrounding natural environment and adversely affect people's health as for example by the risk of contamination of groundwater through nutrient losses by leaching and run-off. In addition, for energy production purposes, elevated fertilization levels may increase the mineral and ash contents in the harvested biomass, which can cause combustion problems including corrosion, slagging, fouling, and environmentally harmful emission.

The available information on studies that have evaluated the effects of fertilization on productivity and carbon storage in the soils are limited and generally concern short-term field studies or pot studies. In a 6-year study, for example, Angelini et al. [3] compared high nitrogen fertilized with unfertilized giant reed and concluded that fertilization mostly affect the initial 4 years of crop growth. In a 3-year trial, Di Candilo et al. [11] also found that the main effects of $\mathrm{N}$ fertilization were evident during the initial years of giant reed and that this effects where even more marked when organic fertilizer were used. Similarly, Cosentino et al. [7] in a 4-year study in South Mediterranean indicated that nitrogen fertilization had significant effects during the first year; however, irrigation was, understandably, the main determinant of biomass yield given the semi-arid environment, whereas information on fertilization requirements of mature and fully productive plants is almost completely inexistent. The putative low input requirements of most perennial grasses reported in the literature based in time-limited studies is somewhat contradictory, leading to great confusion on which dose to apply, or when and where to fertilize these crops [12-16]. Moreover, it is reported for other clonal rhizomatous plants similar to giant reed that the storage capacity of nutrients decreases with age in older rhizomes [17]. In a 3-year study, Kering et al. [16] attributed to giant reed increased fertilization requirements with 
age due to its greater nutrient removal rates compared to other perennial rhizomatous grasses. Therefore, the determination of appropriate nutrient application times and rates may help to maintain high enough the nutrient status of the plant to sustain stable yields, store carbon in the soil, and prolong its economic life.

Other pot studies indicated that $\mathrm{N}$ fertilization, besides increasing the shoot biomass, increase root biomass and the length of rhizomes [18], while field trials suggested that the high soil organic carbon (SOC) stock found under giant reed was probably derived from its large root biomass [19]. According to Ceotto and Di Candilo [20 ], 7 years of continuous cultivation of well-fertilized (120 kg N and $\mathrm{P} \mathrm{ha}^{-1}$ ) giant reed resulted in a substantial SOC increase $(+42 \%)$ in the top $20 \mathrm{~cm}$ of the soil as compared to annual crops, but the real long-term contribution of increased root biomass on soil carbon storage is not known, or if the increasing trend will be maintained as the stand become older. Moreover, it is not known if the stored $\mathrm{C}$ will remain after the crop is removed or it will be released even earlier when the stand vitality starts to decline. Moreover, the large and wide ranging number of recently published carbon sequestration evaluations, encouraged by "aggressive" environmental and bioenergy policies, seems to be mainly based on a relatively short list of short-/medium-term trials limiting the ability to accurately determine the real potential to contribute to the buildup of in situ carbon and nitrogen stocks and therefore the overall suitability of giant reed as bioenergy feedstock.

These uncertainties have a huge potential to misleading directions and spurious conclusions. Therefore, long-term studies have the potential to ensure high and stable productivity of giant reed through a more accurate determination of the real value of management practices, such as fertilization, in a carbon-based bio-economy. This study aimed to evaluate the effects of different nitrogen fertilization levels on biomass production and SOC accumulation in a long-term giant reed stand.

\section{Materials and Methods}

\section{Crop Culture}

A field study was carried out at the experimental farm of Bologna University, in Ozzano, Bologna, Italy (44 33' lat., $11^{\circ} 02^{\prime}$ long., $33 \mathrm{~m}$ a.s.1.), from 1997 to 2012 . From 1998 to 2005 , the field was mainly cultivated with a maize (Zea mays)-wheat (Triticum aestivum) rotation with occasional potato (Solanum 
tuberosum) and sugar beet (Beta vulgaris) insertions in 1998 and 2002, respectively. From 2005 onwards, the field was always cultivated with a maize-wheat rotation. At the giant reed establishment year, half of the field continued to be cultivated with the aforementioned typical rotations, while the other half was planted with a local ecotype of giant reed at a density of 10,000 plants per hectare. The field had a moderate gradient and a clay loam soil texture (34\% sand, $37 \%$ clay, and $29 \%$ silt) with an organic matter content of $1.2 \%$ and a $\mathrm{pH}$ of 7.7 [21]. It was classified, according to the USDA soil taxonomy system, as a Udertic Ustochrepts fine mixed mesic soil. Seedbed preparation was done just before planting and consisted in soil plowing (50 cm depth) and double harrowing in order to facilitate rhizome placement and ensure good contact with the soil. Planting was carried out at the end of April; the rhizomes with a couple of well-developed buds and weighing about $500 \mathrm{~g}$ were placed at $15-20 \mathrm{~cm}$ depth. Before planting, chemical weed control was done using glyphosate ( $3 \mathrm{~L} \mathrm{ha}^{-1}$ ); afterwards, during the establishment year, plots were kept free from weeds by hoeing. From the second year onwards, weed control was no longer necessary. Neither crop disease nor pest was detected during the experimental period; therefore, pest treatments were not necessary. During the establishment year (first year after planting), all plants were grown under similar conditions. In the following years, starting from the second one, three nitrogen fertilization treatments were applied: 0 $\left(\mathrm{N}_{0}\right.$, unfertilized control), $80\left(\mathrm{~N}_{80}\right)$, and $160\left(\mathrm{~N}_{160}\right) \mathrm{kg} \mathrm{N}$ ha ${ }^{-1}$. Nitrogen (as urea) was broadcasted 1 week after $50 \%$ of re-sprouting occurred. Triberti et al. [21] in a nearby long-term rotation trial with similar soil characteristics to the present one determined that exchangeable $\mathrm{K}_{2} \mathrm{O}$ was $367 \mathrm{ppm}$ and assimilable $\mathrm{P}_{2} \mathrm{O}_{5}$ was $5.72 \mathrm{ppm}$. Then, since these clay soils are rich in $\mathrm{K}$, it is assumed that $\mathrm{K}$ was not a limiting factor and therefore was not applied. Moreover, in order to reduce potential depleting effects of the long-term plantation, a basal dressing of $44 \mathrm{~kg} \mathrm{ha}^{-1}$ of $\mathrm{P}$ as triple superphosphate was applied before the stand establishment. A total of 12 plots were arranged according to a completely randomized block design with four replications. In the annual rotations, the conventional agronomic management practices used in the study area were carried out. Briefly, soils were prepared immediately after the harvest with a rotary disc plow to a depth of 30-35 cm and then harrowed (10 cm depth). Wheat was sowed in October and harvested in June each year, while maize was sowed in April and harvested in September. Wheat was usually fertilized at seeding time with $80 \mathrm{~kg} \mathrm{P}_{2} \mathrm{O}_{5} \mathrm{ha}^{-1}$; potassium fertilization was not necessary. $\mathrm{N}$ fertilization $\left(180 \mathrm{~kg} \mathrm{~N}^{-1}\right)$ was done in two fractions, at mid tillering stage and at the beginning of stem elongation. 
Maize usually received a higher fertilization rate (about $250 \mathrm{~kg} \mathrm{ha}^{-1}$ of $\mathrm{N}$ in the form of urea). Preventively, biammonium phosphate was also distributed during the initial crop development phase. In both cases, weed control was done with post emergence herbicide mixtures including grass killers. Daily changes in air temperature and daily rainfall were recorded along the growing cycles at a nearby meteorological station. Based on the available data and following Vicente-Serrano et al. [22], potential evapotranspiration (PET) was calculated. Then, the difference (Di) between precipitation and PET was estimated in order to determine periods of water surplus or deficit along all growing cycles as an indication of drought periods or years.

\section{Aboveground Data Collection}

From the establishment year onwards, harvests were carried out on a standing natural drying crop at the end of each growing season during wintertime (late January to early February). Manual harvest was done by cutting the stems at about $5 \mathrm{~cm}$ from the soil surface in the central part of each plot on an area of $6 \mathrm{~m}^{2}$ (individual plot size was $6 \mathrm{~m} \times 5 \mathrm{~m}$ ); afterwards, the entire experimental area was machine harvested. The cut material was weighed to determine fresh weight. Dry matter yield was determined on sub-samples by oven drying at $105^{\circ} \mathrm{C}$ to constant weight. At the $5^{\text {th }}, 7^{\text {th }}, 10^{\text {th }}, 13^{\text {th }}$, and $16^{\text {th }}$ growing season, sub-samples of $200 \mathrm{~g}$ were collected, dried at $60{ }^{\circ} \mathrm{C}$, and milled for standard biomass total nitrogen analysis, determined by the Kjeldahl digestion method. These data was used to calculate the nitrogen removed by crop as the product of nutrient concentration and dry biomass yield. Nitrogen use efficiency (NUE) was calculated following Beale and Long [23] as the ratio of dry biomass production and nitrogen removed by the crop $(\mathrm{g} / \mathrm{g})$. Therefore, this value indicates the total biomass produced per unit of nitrogen taken up by the crop. Apparent recovery nitrogen efficiency (ARE) was calculated as ratio of nitrogen removed by the crop and amount of nitrogen fertilizer applied.

\section{$\mathrm{N}$ and $\mathrm{C}$ Inputs to the Soil}

Soil core samples were taken at the end of the $16^{\text {th }}$ growing season at $0-15$, 15-30, and 30-60 cm depth intervals in each replication for $\mathrm{N}$ and soil organic carbon (SOC) concentration. Additional soil cores were also taken from the adjacent field cultivated with the long-term maize-wheat annual rotation. SOC was determined by a CF-IRMS, Delta V Advantage (Thermo Scientific Inc.) mass spectrometer in $300 \mu \mathrm{g}$ samples, although the instrument allows measuring both total and organic $\mathrm{C}$; in the present case, only organic $\mathrm{C}$ 
was determined. Before analysis, coarse roots were removed by passing the soil through a fine sieve of $2 \mathrm{~mm}$. Then, the separated soil samples were finely grounded for analysis. Following Post and Kwon [24], Kahle et al., [25], Hansen et al. [26], and Ceotto and Di Candilo [20], the effects of alternative land uses on SOC content was evaluated; that is, the $\mathrm{C}$ gain was calculated as the difference between giant reed plots and the annual rotation. SOC and N stocks $\left(\mathrm{Mg} \mathrm{ha}^{-1}\right.$ ) were calculated by multiplying soil bulk density, depth interval, and $\mathrm{C}$ and $\mathrm{N}$ concentrations. Bulk density was determined to be in average $1.42,1.40$, and $1.33 \mathrm{~g} \mathrm{~cm}^{-3}$ in the $0-25,25-45$, and $45-85 \mathrm{~cm}$ layers, respectively. For that purpose, soil core samples were taken periodically from December 2004 until September 2006 in a nearby field to the present study [27]. Even though bulk density depth intervals do not align perfectly with those for the SOC determination, we consider that bulk density values may represent well the bottom end of the soil columns taken for soil $\mathrm{C}$ analysis, as the soil cores taken for bulk density analysis were taken at midway of the indicated depth intervals.

\section{Statistical Analysis}

Homoscedasticity of data was checked by the Bartlett's test prior analysis of variance (ANOVA). Subject factors (individual plots) were assumed as random factors while treatments and years as fixed factors. When ANOVA revealed significant differences among means $(P \leq 0.05)$, the pairwise comparison Fisher's LSD tests were used to separate means into statistically different groups $(P \leq 0.05)$.

\section{Results}

\section{Meteorological Trend}

The monthly rainfall and average temperature from 1998 to 2012 followed the typical trend of the weather conditions in Northern Italy (Fig. 1). In general, air temperatures that increased from March $(9.3 \pm 1.2)$ to August $(25.0 \pm 1.7)$ characterized the active growing period of giant reed. Then, from September onwards, average temperatures started to decrease as the plants enter the reproductive stage. Across years, seasonal maximum values above $25{ }^{\circ} \mathrm{C}$ were registered between July and August. Air temperatures decreased rapidly from November with the coldest months (December and January) coinciding with the dormant period of the crop. There was a considerable variability in rainfall amount within and between years (Fig. 1), but the typical rainfall distribution pattern followed two peaks: one during winter-autumn months and the other 
during spring time, with a long dry summer period (mainly July-August) in between with an average precipitation of only $41 \mathrm{~mm}$. Along the years, the driest summer periods, with the lowest Di, were registered in 1998, 2003, 2007,2009 , and 2012 with an average precipitation of 32, 14, 23, 33, and $10 \mathrm{~mm}$, respectively, from June to August.

\section{Fig. 1}

Monthly rainfall, average temperature from 1998 to 2012, and periods of water surplus or deficit (Di) along all growing cycles at the experimental site (Ozzano, Italy $44^{\circ} 33^{\prime}$ lat., $11^{\circ} 02^{\prime}$ long., $33 \mathrm{~m}$ a.s.l). The largest water deficits were registered in the summers of 1998, 2003, 2007, 2009, and 2012. Di was calculated as the difference between precipitation and estimated potential evapotranspiration
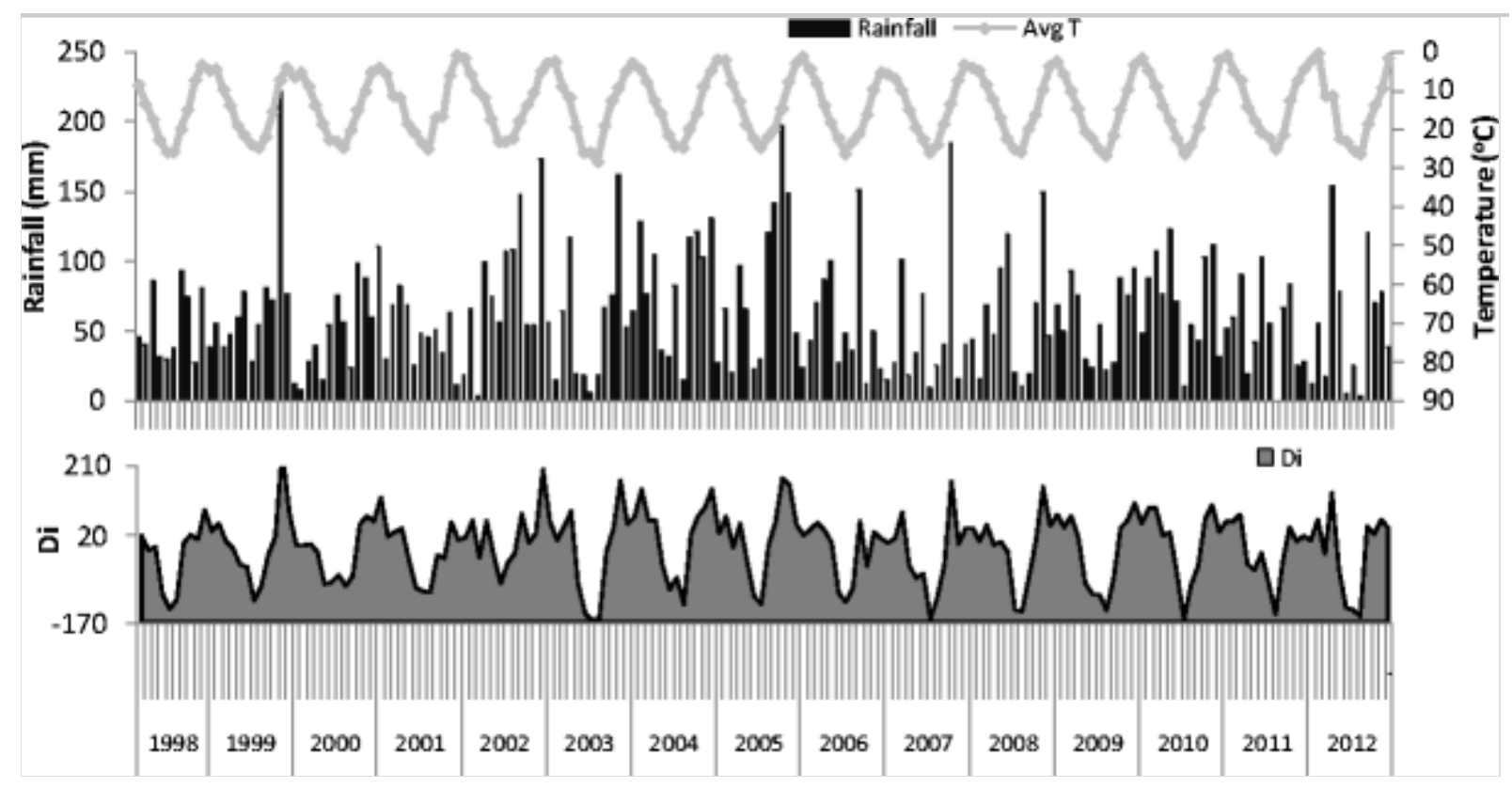

\section{Aboveground Dry Biomass Production}

Figure 2 shows the dry biomass yield of fertilized and unfertilized plots throughout the entire lifetime of giant reed. A fertilization level of $\mathrm{N}_{160}$ resulted in the highest yields. On the other hand, a significant difference between the unfertilized and $\mathrm{N}_{80}$ treatment was not evident at any growing season. The averaged yields from the $2^{\text {nd }}$ to $16^{\text {th }}$ growing season were 16.2 , 17.1 , and $19.5 \mathrm{Mg}$ ha $^{-1}$ in the $\mathrm{N}_{0}, \mathrm{~N}_{80}$, and $\mathrm{N}_{160}$ treatments, respectively. As the years went by, the cumulative dry biomass yield differences between the control and the highest fertilization dose increased gradually. In fact, at the last sampling season, the cumulative yield in the unfertilized treatment was $17 \%$ lower than in the $\mathrm{N}_{160}$ treatment, while after 1 year of imposing the 
treatments, the yield difference was only $8 \%$ (Fig. 2a). During the productive lifespan of giant reed, three peak yielding phases were observed in the $\mathrm{N}_{160}$ treatment (Fig. $2 \mathrm{~b}$ ): at the $5^{\text {th }}, 10^{\text {th }}$, and $14^{\text {th }}$ growing season with average yields of $26.1,25.3$, and $17.6 \mathrm{Mg} \mathrm{ha}^{-1}$, respectively. In contrast to the highest fertilization treatment, the unfertilized plants reached its maximum productivity (23.4 $\mathrm{Mg} \mathrm{ha}^{-1}$ ) on the fourth growing season (1 year earlier than in the fertilized plots); afterwards, a quasi-continuous yield reduction up to $7.5 \mathrm{Mg} \mathrm{ha}^{-1}$ in the last growing season was observed (Fig. 2b). Moreover, the highest yield differences between the $\mathrm{N}_{160}$ treatment and the long-term average of $\mathrm{N}_{0}$ was reached during the fifth growing season with about $61 \%$ higher productivity. These significantly higher yielding differences extended from the third until the tenth growing season. Afterwards, such higher yield differences started to decrease towards the last growing season. In fact, at the last two growing seasons, the yield differences were significantly lower, with a reduction of about $28 \%$ from the long-term average of $\mathrm{N}_{0}$. Important to note that such relative yield decrements, and therefore actual yields, were even lower than during the establishment year. As for the $\mathrm{N}_{80}$ treatment, the relative yield differences were higher than the long-term average from the fourth to the sixth growing season only; afterwards, a quasi-continuous yield reduction until the last growing season was observed (Fig. 2c, d).

\section{Fig. 2}

Cumulative yield (a), mean yield of the three $\mathrm{N}$ levels per year (b), and box plots of the distribution of relative yield differences ( $\Delta$ yield) between fertilized treatments and the non-fertilized long-term average (from the $2^{\text {nd }}$ to the $16^{\text {th }}$ growth cycle) treatment (c, d). Bold horizontal lines within the boxes indicate the median yield for each year. Boxes represent the approximate upper and lower quartiles. Multiplication sign indicates the mean relative yield differences and the vertical whiskers indicate the standard deviations of the mean. Horizontal dotted lines indicate the positive and negative LSD value. $\mathrm{N}_{0}$, unfertilized control; $\mathrm{N}_{80}$ and $\mathrm{N}_{160}, 80$ and $160 \mathrm{~kg} \mathrm{~N}$ ha 

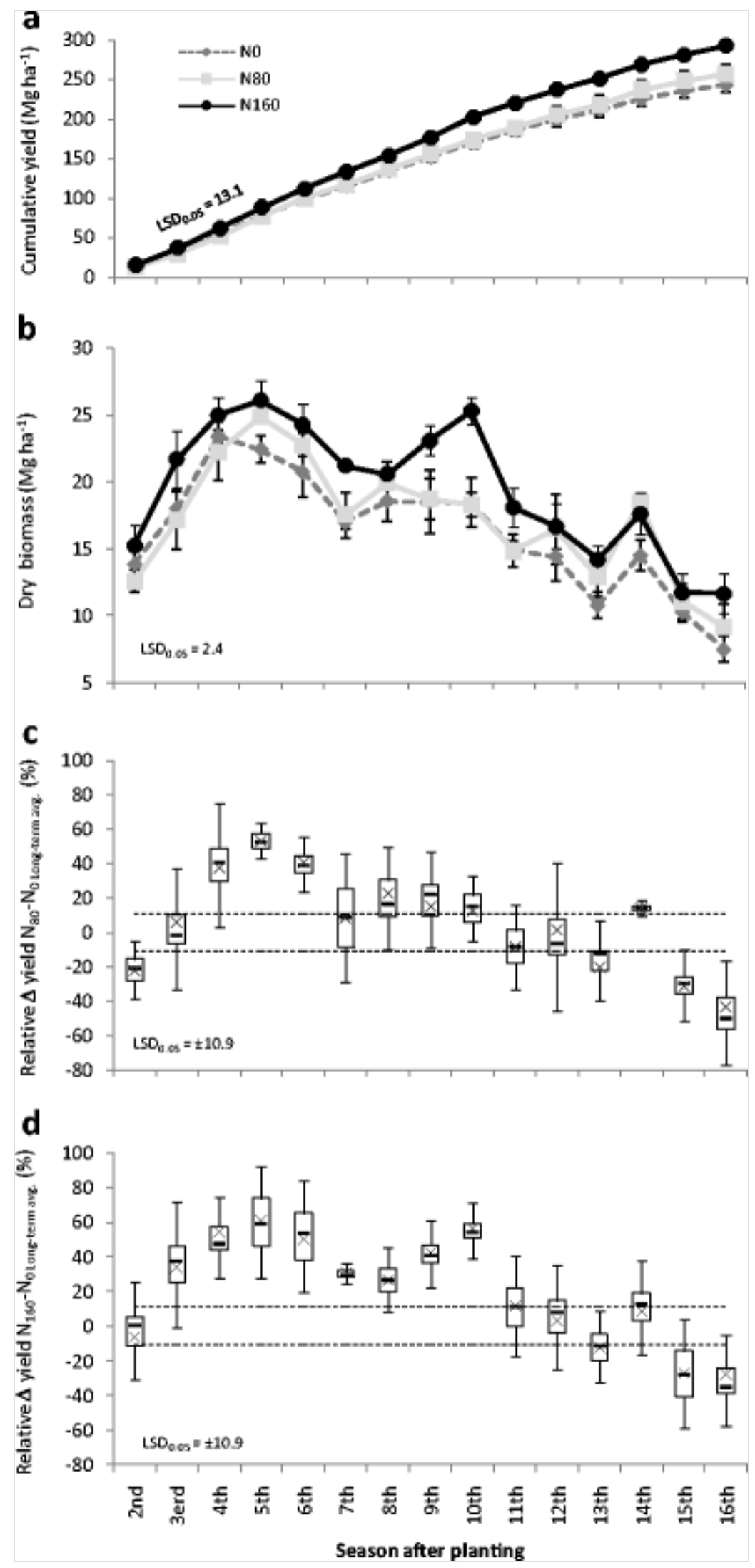

\section{Nitrogen Removal}

The plant $\mathrm{N}$ content in the $\mathrm{N}_{80}$ and $\mathrm{N}_{160}$ treatments was not statistically different (Table 1); however, it increased significantly from 0.49 to $0.61 \%$ in the $\mathrm{N}_{0}$ and $\mathrm{N}_{160}$, respectively, and from 0.45 to $0.62 \%$ as the stand become older (Table 1). In general, all fertilized plants, due to a higher biomass yield, 
removed more nitrogen than the control treatment; significant differences $(P \leq$ $0.05)$ were found only between the highest fertilization rate and the control treatment. Averaged across the $5^{\text {th }}$ to the $16^{\text {th }}$ growing season, plants that received $160 \mathrm{~kg} \mathrm{~N}^{-1}{ }^{-1}$ removed $117 \mathrm{~kg} \mathrm{~N}$ ha $^{-1}$, while with a $80 \mathrm{~kg} \mathrm{~N}^{-1}$ dose, the plants removed more $\mathrm{N}$ than was applied $\left(90 \mathrm{~kg} \mathrm{ha}^{-1}\right)$. When no $\mathrm{N}$ was applied, giant reed removed in average $75 \mathrm{~kg} \mathrm{~N} \mathrm{ha}^{-1}$. In contrast, nitrogen use efficiency followed an inverse pattern; that is, lower nitrogen use efficiencies were generally associated with high application rates $(160 \mathrm{~kg}$ $\mathrm{N}$ ha ${ }^{-1}$ ). From the $5^{\text {th }}$ to the $16^{\text {th }}$ growing season, average nitrogen use efficiency of 180, 200, and $219 \mathrm{~g} \mathrm{~g}^{-1}$ were obtained in the $\mathrm{N}_{160}, \mathrm{~N}_{80}$, and $\mathrm{N}_{0}$ treatments, respectively (Table 1 ). In addition, the apparent recovery nitrogen efficiency followed a similar pattern, lower fertilization rates resulted in greater recovery efficiency, but at the last growing seasons, the differences between treatments become smaller.

\section{Table 1}

Yearly variation in $\mathrm{N}$ concentration, $\mathrm{N}$ removal, NUE, and ARE as affected by different fertilization rates along different growing season

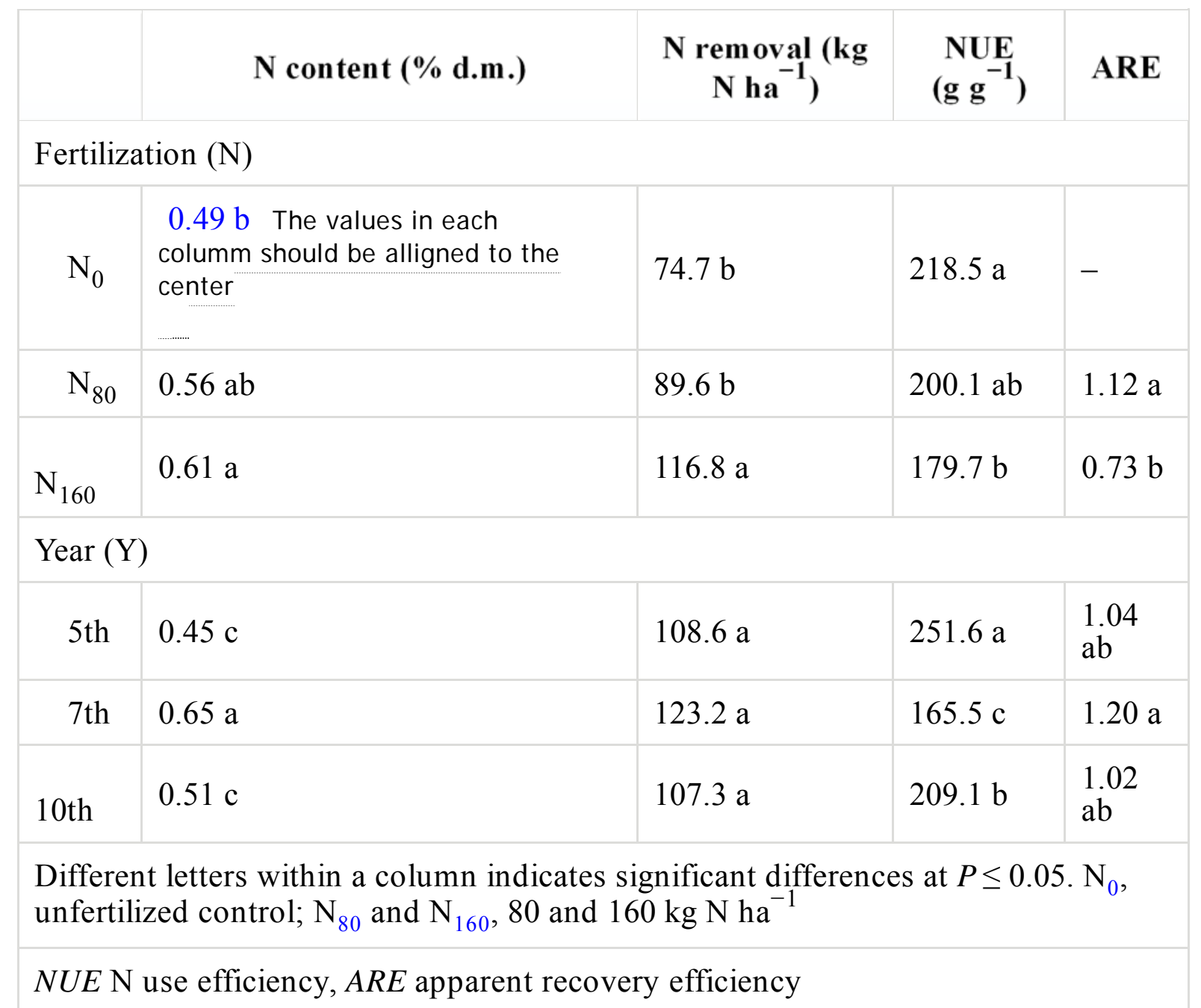




\begin{tabular}{|c|c|c|c|c|}
\hline & $N$ content $(\%$ d.m.) & $\begin{array}{l}\text { N removal }(k g \\
\left.\mathrm{N} \mathrm{ha}^{-1}\right)\end{array}$ & $\begin{array}{l}\text { NUE } \\
\left(g^{-1}\right)\end{array}$ & ARE \\
\hline 13 th & $0.54 \mathrm{bc}$ & $69.1 \mathrm{~b}$ & $202.5 \mathrm{bc}$ & $\begin{array}{l}0.73 \\
\mathrm{bc}\end{array}$ \\
\hline 16 th & $0.62 \mathrm{ab}$ & $60.4 \mathrm{~b}$ & $168.4 \mathrm{c}$ & $0.63 \mathrm{c}$ \\
\hline \multicolumn{5}{|c|}{ Fixed effect } \\
\hline $\mathrm{N}$ & 0.013 & 0.000 & 0.047 & 0.000 \\
\hline $\mathrm{Y}$ & 0.001 & 0.000 & 0.000 & 0.007 \\
\hline $\mathrm{Y}^{\mathrm{N} \times}$ & 0.890 & 0.728 & 0.846 & 0.573 \\
\hline \multicolumn{5}{|c|}{$\begin{array}{l}\text { Different letters within a column indicates significant differences at } P \leq 0.05 . \mathrm{N}_{0} \text {, } \\
\text { unfertilized control; } \mathrm{N}_{80} \text { and } \mathrm{N}_{160}, 80 \text { and } 160 \mathrm{~kg} \mathrm{~N} \mathrm{ha}\end{array}$} \\
\hline
\end{tabular}

\section{Soil Carbon and Nitrogen Storage}

At the $16^{\text {th }}$ growing season, mean SOC and $\mathrm{N}$ stocks beneath giant reed were significantly higher in the $\mathrm{N}_{160}$ than in the $\mathrm{N}_{0}$ treatment (30 and $24 \mathrm{Mg}$ $\mathrm{C} \mathrm{ha}^{-1}$ and 3.0 and $2.6 \mathrm{Mg} \mathrm{N}^{-1}$, respectively). No significant differences, however, were found between $\mathrm{N}_{160}$ and $\mathrm{N}_{80}$ treatments in the case of $\mathrm{N}$ stocks only (Table 2). Regardless of the fertilization level, the largest SOC and N stocks were found in the upper soil layers $(0-15 \mathrm{~cm}$ depth), but it is important to note that the higher soil $\mathrm{C}$ and $\mathrm{N}$ stocks in the deepest layer $(0.30-0.60 \mathrm{~m}$ depth) result from the twice as large soil depth considered in the calculation. In addition to that, the largest contribution of giant reed to SOC change was observed in top $15 \mathrm{~cm}$ of the soil profile, with about $12 \mathrm{Mg} \mathrm{C}^{-1}{ }^{-1}$ higher in the $\mathrm{N}_{160}$ than in the steady state annual rotation and about $6 \mathrm{Mg} \mathrm{C}^{-1}$ more than in the $\mathrm{N}_{0}$ (Table 2).

\section{Table 2}

Soil $\mathrm{N}$, soil organic carbon, and $\mathrm{C}$ gains as affected by different fertilization rates along different the growing season. $\mathrm{C}$ gains were estimated as the difference between soil organic carbon of the individual treatments and the adjacent maize-wheat rotation IQ1

$$
\text { Soil N (Mg ha } \left.{ }^{-1}\right) \quad \text { Soil C }\left(\mathrm{Mg} \mathrm{ha}^{-1}\right) \quad \mathrm{C}_{\text {gain }}\left(\mathrm{Mg} \mathrm{ha}^{-1}\right)
$$

Different letters within a column indicates significant differences at $P \leq 0.05 . \mathrm{N}_{0}$, unfertilized control; $\mathrm{N}_{80}$ and $\mathrm{N}_{160}, 80$ and $160 \mathrm{~kg} \mathrm{~N} \mathrm{ha}^{-1}$ 
Soil N (Mg ha $\left.{ }^{-1}\right)$

Soil C $\left(\mathrm{Mg} \mathrm{ha}^{-1}\right)$

$\mathrm{C}_{\text {gain }}\left(\mathrm{Mg} \mathrm{ha}^{-1}\right)$

$0-15$ depth (D)

\begin{tabular}{|c|l|l|l|}
\hline $\mathrm{N}_{0}$ & $2.61 \mathrm{de}$ & $23.77 \mathrm{~b}$ & $6.38 \mathrm{~b}$ \\
\hline $\mathrm{N}_{80}$ & $2.87 \mathrm{~cd}$ & $23.89 \mathrm{~b}$ & $6.50 \mathrm{~b}$ \\
\hline $\mathrm{N}_{160}$ & $3.03 \mathrm{c}$ & $29.65 \mathrm{a}$ & $12.26 \mathrm{a}$
\end{tabular}

15-30 depth (D)

\begin{tabular}{|c|l|l|l|}
\hline $\mathrm{N}_{0}$ & $2.36 \mathrm{e}$ & $16.56 \mathrm{~d}$ & $-0.79 \mathrm{~d}$ \\
\hline $\mathrm{N}_{80}$ & $2.33 \mathrm{e}$ & $16.52 \mathrm{~d}$ & $-0.84 \mathrm{~d}$ \\
\hline $\mathrm{N}_{160}$ & $2.46 \mathrm{e}$ & $18.65 \mathrm{~cd}$ & $1.29 \mathrm{~cd}$
\end{tabular}

30-60 depth (D)

\begin{tabular}{|c|l|l|l|}
\hline $\mathrm{N}_{0}$ & $3.88 \mathrm{a}$ & $23.49 \mathrm{~b}$ & $4.29 \mathrm{bc}$ \\
\hline $\mathrm{N}_{80}$ & $3.72 \mathrm{ab}$ & $22.23 \mathrm{bc}$ & $3.03 \mathrm{bc}$ \\
\hline $\mathrm{N}_{160}$ & $3.58 \mathrm{~b}$ & $21.31 \mathrm{bc}$ & $2.10 \mathrm{~cd}$
\end{tabular}

Fixed effect

\begin{tabular}{c|l|l|l}
\hline $\mathrm{N}$ & 0.682 & 0.077 & 0.077 \\
\hline $\mathrm{D}$ & 0.000 & 0.000 & 0.000 \\
\hline $\mathrm{N} \times \mathrm{D}$ & 0.024 & 0.044 & 0.044 \\
\hline
\end{tabular}

Different letters within a column indicates significant differences at $P \leq 0.05$. $\mathrm{N}_{0}$, unfertilized control; $\mathrm{N}_{80}$ and $\mathrm{N}_{160}, 80$ and $160 \mathrm{~kg} \mathrm{~N}$ ha $^{-1}$

\section{Discussion}

\section{Long-Term Productivity}

Along the 16 growing cycles, variable yielding phases were observed. The depressed production years somehow coincided with very long and dry summer periods where severe water deficits were observed (Figs. 1 and 2), suggesting that, although giant reed is broadly recognized as a very drought tolerant crop [7, 10], such prolonged drought periods is a significant growthrestricting factor also for giant reed. Moreover, our results indicate that the highest productivity and the largest yield difference with the long-term average of unfertilized giant reed (about $27 \mathrm{Mg}$ ha $^{-1}$ and $61 \%$, respectively) was reached during the fifth growing season by the highest fertilization rate 
$\left(160 \mathrm{~kg} \mathrm{~N} \mathrm{ha}^{-1}\right)$ in agreement with the lowest precipitation deficit (Figs. 1 and 2 ). Several authors $[3,5,28]$ reported similar productivity patterns, although the present study was carried out in a marginal agricultural land with a moderate slope and with a lower plant density $\left(10,000\right.$ plants ha $\left.{ }^{-1}\right)$.

High $\mathrm{N}$ fertilization rates helped to sustain relatively high yields regardless of the climatic adversities. In fact, over a period of 9 consecutive years (between the $3^{\text {rd }}$ and $\left.11^{\text {th }}\right)$, productivity was maintained above the overall mean $\left(17.6 \mathrm{Mg} \mathrm{ha}^{-1}\right)$. If no additional fertilization would be applied, such high yielding period would be circumscribed to about 3 years only (between the fourth and sixth). However, considering the marginal, but statistically significant, yield advantages of $\mathrm{N}_{160}$ over $\mathrm{N}_{0}$, applying fertilizers for a prolonged period of time can be unprofitable and unattractive to farmers, as well as unsustainable for the environment, given the burdens of fertilizers application and increase of economic costs from $\mathrm{N}$ fertilization (a total amount of $5.2 \mathrm{t} \mathrm{ha}^{-1}$ of urea were distributed on $\mathrm{N}_{160}$ plots in 16 years).

Our results suggest that nitrogen fertilization determined an increasing trend of biometric parameters regardless of the age of the plant or weather variability across the years (Fig. 1; Table 1). However, this trend was not linear, and the addition of $160 \mathrm{~kg} \mathrm{~N}_{-1}{ }^{-1}$ gave a marginally larger response than $80 \mathrm{~kg} \mathrm{~N}^{-1}{ }^{-1}$. This is partially in contrast to Cosentino et al. [7] who reported that $60 \mathrm{~kg} \mathrm{~N}^{-1}{ }^{-1}$ maximized biomass yield of giant reed. The authors, however, performed their trials in a semi-arid Mediterranean environment where $\mathrm{N}$ fertilization effects can more highly interact with drought stress than in North Italy. The effects of the highest fertilization level, however, increased over time and seemingly helped to retard the decreasing productivity trend clearly seen in the unfertilized plants from the fourth growing season onwards (Fig. 2). In contraposition to short-/medium-term studies such as those of Angelini et al. [3] and Mantineo et al. [5] that indicate that as the plants become more mature their fertilization requirements decrease thank to its nutrient recycle capacity (rizhome/canopy), our results suggest that as the plants become older, such recycling capacity decrease while its dependence on external nutrient supplies increase. In most of the growing cycles evaluated here, the apparent $\mathrm{N}$ recovery efficiency was significantly different between $\mathrm{N}_{160}$ and $\mathrm{N}_{80}$. Considering that the trial was carried out in a marginal soil with relativity low fertility, the well fertilized 5 -year-old plants $\left(160 \mathrm{~kg} \mathrm{~N} \mathrm{ha}^{-1}\right)$ removed 1.5 times more $\mathrm{N}$ than unfertilized plants to produce 1.2 times more biomass, while well fertilized 16-year-old 
plants removed 2.5 times more $\mathrm{N}$ to produce 1.5-1.6 times more biomass than unfertilized plants (Fig. 2, Table 1). Therefore, even though harvest was carried out when plants were dormant, the high $\mathrm{N}$ removal rates indicate the large fertilization requirements of giant reed, which may be accentuated by the decreased rhizome vitality and its capacity to recycle nutrients with plant age [17]. Therefore, besides economical benefits, sustainable fertilization and harvesting management practices have to take into account that as the plants mature, large amounts of nutrients are removed in the harvested biomass. In addition, the nutrient recycling capacity of older rhizomes seems to be insufficient to maximize productivity; therefore, the external supply of nutrients, either as organic or mineral fertilizers, should be carefully considered to economically maintain long-term productivity and soil fertility.

\section{Soil Carbon Storage}

At the last growing season, the total $\mathrm{C}$ input in the top $60 \mathrm{~cm}$ of soil was about $29 \%$ higher in the $\mathrm{N}_{160}$ treatment than in the nearby annual rotation system, while in the case of the $\mathrm{N}_{0}$ treatment, the increase was only $18 \%$, accounting for an average SOC storage of 1.0 and $0.6 \mathrm{MgC} \mathrm{ha}^{-1}$ year ${ }^{-1}$, respectively, in the 16-year period (Table 2). Even though there is a general consensus that stands of perennial grasses slowly store $\mathrm{C}$ in the soil with time [29, 30], changes in SOC content in the non-fertilized giant reed plots were in the lower range of what is reported in the literature for other perennial grasses [20, 31-33]. These slow and gradual changes are usually obscured by the high background levels of C already present in the soil [34] as was the case of the adjacent long-term annual maize-wheat rotation used as reference plot in this study. Fuentes et al. [35] indicated that 2-year annual rotations combined with no tillage are an efficient system to maximize $\mathrm{C}$ retention in the topsoil aggregates. Besides that, our results are in agreement with a long-term (15 years) land conversion simulation from cotton (Gossypium hirsutum) to switchgrass (Panicum virgatum) that indicated that SOC decreased when switchgrass was not fertilized, was unchanged when $45 \mathrm{~kg}$ $\mathrm{N} \mathrm{ha}^{-1}$ was applied, and increased when $90-135 \mathrm{~kg} \mathrm{~N}^{-1}{ }^{-1}$ were applied [36].

Taking into consideration, however, $\mathrm{CO}_{2}$ emissions due to fuel consumption and agronomic inputs (calculated according to Angelini et al., Fazio and Monti [4, 37] and considering $88.6 \mathrm{~g}$ of $\mathrm{CO}_{2}$ eq. $\mathrm{L}^{-1}$ emissions for diesel use during the crop management operations, assuming 126 and $53 \mathrm{~L} \mathrm{ha}^{-1}$ of diesel for crop establishment and harvest operations, respectively, in the $\mathrm{N}$ treatments and a $10 \%$ lower in the unfertilized plots. As for $\mathrm{N}$ production, 
$6340 \mathrm{~g} \mathrm{CO}_{2}$ eq. $\mathrm{kg}^{-1}$ of $\mathrm{N}$ applied were considered. Finally, for biomass transport, transformation, and conditioning and distribution $16.5 \mathrm{~g} \mathrm{CO}_{2}$ eq. $\mathrm{MJEtOH}^{-1}$ and a $\mathrm{MJ}_{\text {wood }} / \mathrm{MJ}_{\mathrm{EtOH}}$ yield of 0.3428 were considered), we estimated that the net SOC stock reported above could be reduced by $67 \%$ in the $\mathrm{N}_{160}$ and $39 \%$ in the $\mathrm{N}_{0}$. The fraction of $\mathrm{CO}_{2}$ emission due to $\mathrm{N}$ fertilization could be even larger if $\mathrm{N}_{2} \mathrm{O}$ emissions are taken into account. Currently, however, there is no agreement on the proportionality of $\mathrm{N}_{2} \mathrm{O}$ emissions and the amount of $\mathrm{N}$ fertilizer applied, neither on the weight of $\mathrm{N}_{2} \mathrm{O}$ emissions from agricultural systems. Ranges of emission factors reported in the literature are highly variable, going from 1 to $5 \%$ or more [38-41]. In any case, the $\mathrm{N}$ removed in the aboveground biomass and the $\mathrm{N}$ recovery capacity of giant reed was high and close to the amount of applied fertilizers (Table 1), suggesting that giant reed is particularly efficient in using $\mathrm{N}$; therefore, it could be assumed that low $\mathrm{N}$ amounts remained in the soil with consequent low $\mathrm{N}$ losses from the system. In fact, at the deepest soil layer, $\mathrm{N}$ was depleted in the $\mathrm{N}_{160}$ treatment in comparison to the control (Table 2), suggesting reduced leaching and reallocation of deep nitrogen to shallow layers through root uptake [42]. In any case, besides the benefits of increased SOC on soil quality (fertility, water holding capacity, soil quality, etc.) and ecosystem services, the gross $\mathrm{C}$ gain of giant reed seems to provide a substantial SOC input to the topsoil. It is important to note, however, that although the SOC in the whole soil profile (0-60 cm depth) in the $\mathrm{N}_{160}$ treatment was about $29 \%$ higher than in the annual rotation, the difference was not statistically significant, most probably due to variable SOC accumulation and mineralization rates across repetitions and tillage systems. It cannot be excluded, either, that the redistribution effects of soil tillage in the annual rotation had affected the SOC dynamics and content in the considered soil depth. In any case, effects of high fertilization rates on increased SOC and $\mathrm{N}$ stocks were significant only on the top 0-15 cm soil layer (Table 2). Similar results were observed by Sarkhot et al. [19] in a survey of 125 locations with giant reed and indicated that out of four $\mathrm{C}$ pools (total, organic, inorganic, and available (liable) soil C), the most sensitive to changes in soil depth was the available soil $\mathrm{C}$. Then, this decreasing pattern with depth could be attributed to an increased input of organic matter from rhizomes, canopy litter, and mainly from fine root mass to surface soil layers. It was indeed observed that grasses allocate about $60 \%$ of their carbon to the roots, while annual crops about $40 \%$ only [43]. In addition to that, Monti and Zatta [44] found that giant reed had the most homogeneous root distribution among other perennial and annual grasses and that $60 \%$ of its roots are located in the 
top $40 \mathrm{~cm}$ of the soil.

In conclusion, depending on the factors taken into consideration (e.g., $\mathrm{N}$ input levels, soil depth, GHG emissions, etc.), the C storage capacity of a long-term giant reed plantation was highly variable, but what clearly emerged from this study was that high $\mathrm{N}$ fertilization rates result in marginal increments in yield in the long-term, but in substantial increments in SOC and N gross stocks, especially in surface soil layers, an aspect of ecological significance as topsoil layers play an important role in the $\mathrm{C}$ uptake and release from the ecosystem. However, the marginal increase in yields by $\mathrm{N}$ fertilization (about $3 \mathrm{Mg}$ ha $^{-1}$ year ${ }^{-1}$ in the case of $\mathrm{N}_{160}$ compared to $\mathrm{N}_{0}$ ) might not be worthwhile neither an attractive management practice for a farmer, considering all the economic and environmental burdens of $\mathrm{N}$ fertilizer application.

\section{References}

1. Venendaal R, Jorgensen U, Fosters CA (1997) European energy crops: a synthesis. Biomass Bioenergy 13:147-185

2. Hidalgo M, Fernandez J (2000) Biomass production of ten populations of giant reed (Arundo donax L.) under the environmental conditions of Madrid (Spain). In: Biomass for energy and industry: proceeding of the first world conference, Sevilla, Spain. pp. 1881-1884

3. Angelini LG, Ceccarini L, Bonari E (2005) Biomass yield and energy balance of giant reed (Arundo donax L.) cropped in central Italy as related to different management practices. Eur J Agron 22:375-389

\section{Angelini LG, Ceccarini L, Nassi o Di Nasso N, Bonari E (2009) Comparison of Arundo donax L. and Miscanthus x giganteus in a long-term field experiment in central Italy: analysis of productive characteristics and energy balance. Biomass Bioenergy 33:635-643}

5. Mantineo M, D'Agosta GM, Copani V, Patanè C, Cosentino SL (2009) Biomass yield and energy balance of three perennial crops for energy use in the semi-arid Mediterranean environment. Field Crop Res 114:204-213
6. Nassi o Di Nasso N, Angelini LG, Bonari E (2010) Influence of fertilisation and harvest time on fuel quality of giant reed (Arundo donax L.) in central Italy. Eur J Agron 32:219-227 


\section{Cosentino SL, Scordia D, Sanzone E, Testa G, Copani V (2014)}

Response of giant reed (Arundo donax L.) to nitrogen fertilization and soil water availability in semi-arid Mediterranean environment. Eur J Agron 60:22-32

8. Lewandowski I, Scurlock JMO, Lindvall E, Christou M (2003) The development and current status of perennial rhizomatous grasses as energy crops in the US and Europe. Biomass Bioenergy 25:335-361

9. Zegada-Lizarazu W, Elbersen W, Cosentino SL, Zatta A, Alexopoulou E, Monti A (2010) Agronomic aspects of future energy crops in Europe. Biofuels Bioprod Biorefin 4:674-691

\section{Zegada-Lizarazu W, Parrish D, Berti M, Monti A (2013) Dedicated} crops for advanced biofuels: consistent and diverging agronomic points of view between the USA and the EU-27. Biofuels Bioprod Biorefin $7: 715-731$

\section{Di Candilo M, Ceotto E, Librenti I, Faeti V (2010) Manure} fertilization on dedicated energy crops: productivity, energy and carbon cycle implications. In: Proceedings of the $14^{\text {th }}$ Ramiran international conference of the FAO ESCORENA Network on the recycling of agricultural, municipal and industrial residues in agriculture

12. Sanderson MA, Reed RL, McLaughlin SB, Wullschleger SD, Conger BV, Parrish DJ, Wolf DD, Taliaferro C, Hopkins AA, Ocumpaugh WR, Hussey MA, Read JC, Tischler CR (1996) Switchgrass as a sustainable bioenergy crop. Bioresour Technol 56:83-93

13. Christou M, Mardikis M, Alexopoulou E (2001) Research on the effect of irrigation and nitrogen upon growth and yields of Arundo donax L. in Greece. Asp Appl Biol 65:47-55

14. Haque M, Epplin FM, Taliaferro CM (2009) Nitrogen and harvest frequency effect on yield and cost for four perennial grasses. Agron J 101:1463-1469

15. Knoll JE, Anderson WF, Strickland TC, Hubbard RK, Malik R (2012) Low-input production of biomass from perennial grasses in the coastal plain of Georgia, USA. Bioenergy Res 5:206-214 
16. Kering MK, Butler TJ, Biermacher JT, Guretzky JA (2012) Biomass yield and nutrient removal rates of perennial grasses under nitrogen fertilization. Bioenergy Res 5:61-70

17. Klimešová J, Klimeš L (1996) Effects of rhizome age and nutrient availability on carbohydrate reserves in Rumex alpinus rhizomes. Biologia, Bratislava 51:457-461

18. Quinn LD, Rauterkus MA, Holt JS (2007) Effects of nitrogen enrichment and competition on growth and spread of giant reed (Arundo donax). Weed Sci 55:319-326

19. Sarkhot DV, Grunwald S, Geb Y, Morgan CLS (2012) Total and available soil carbon fractions under the perennial grass Cynodon dactylon (L.) Pers and the bioenergy crop Arundo donax L. Biomass Bioenergy 41:122-130

20. Ceotto E, Di Candilo M (2011) Medium-term effect of perennial energy crops on soil organic carbon storage. Ital J Agron 33:212-217

21. Triberti L, Stefanelli G, Marenghi A, Toderi G (2000) Crop rotation and soil tillage effects observed in a hilly area using simplified crop systems. Note III. Influence on soil pH and organic matter, nitrogen, phosphorous content in the soil. Rivista di Agronomia 34:269-275 (in Italian)

22. Vicente-Serrano SM, Begueria S, Lopez-Moreno JI (2010) A multiscalar drought index sensitive to global warming: the standardized precipitation evapotranspiration index. J Clim 23:1696-1718

23. Beale CV, Long SP (1997) Seasonal dynamics of nutrient accumulation and partitioning in the perennial C4-grasses Miscanthus $x$ giganteus and Spartina cynosuroides. Biomass Bioenergy 12:419-428

24. Post WM, Kwon KC (2000) Soil carbon sequestration and land-use change: processes and potential. Glob Chang Biol 6:317-327

25. Kahle P, Beuch S, Boelcke B, Leinweber P, Schulthen HR (2001) Cropping of Miscanthus in Central Europe: biomass production and influence on nutrients and soil organic matter. Eur J Agron 15:171-184 
26. Hansen EM, Christensen BT, Jensen LS, Kristensen K (2004) Carbon sequestration in soil beneath long-term Miscanthus plantations as determined by ${ }^{13} \mathrm{C}$ abundance. Biomass Bioenergy 26:97-105

27. Salvatorelli F (2006) Studio delle proprietà idrologiche in suoli agrari, Ph.D. Thesis. Bologna University, Italy

28. Cosentino SL, Copani V, D'Agosta GM, Sanzone E, Mantineo M (2006) First results on evaluation of Arundo donax L. clones collected in southern Italy. Ind Crop Prod 23:212-222

29. Rowe RL, Street NR, Taylor G (2009) Identifying potential environmental impacts of large-scale deployment of dedicated bioenergy crops in the UK. Renew Sust Energ Rev 13:271-290

30. Skinner H, Zegada-Lizarazu W, Schmidt JP (2012) Environmental impacts of switchgrass management for bioenergy production. In: Monti A (ed) Switchgrass: a valuable biomass crop for energy. Springer, London, pp $129-152$

31. Gebhart DL, Johnson HB, Mayeux HS, Polley HWJ (1994) The CRP increases soil organic carbon. J Soil Water Conserv 49:488-492

32. Garten CT, Wullschleger SD (2000) Soil carbon dynamics beneath switchgrass as indicated by stable isotope analysis. J Environ Qual 29:645-553

33. IPCC (2003) Good practice guidance for land use, land-use change and forestry. In: Penman J, Gytarsky M, Hiraishi T, Krug T, Kruger D, Pipatti R, Buendia L, Miwa K, Ngara T, Tanabe K, Wagner F (eds) National Greenhouse Gas Inventories Programme. pp. 593

34. Lockwell J, Guidi W, Labrecque N (2012) Soil carbon sequestration potential of willows in short-rotation coppice established on abandoned farm lands. Plant Soil 360:299-318

35. Fuentes M, Hidalgo C, Etchevers J, De León F, Guerrero A, Dendooven L, Verhulst N, Govaerts B (2012) Conservation agriculture, increased organic carbon in the top-soil macro-aggregates and reduced soil $\mathrm{CO}_{2}$ emissions. Plant Soil 355:183-197 
36. Chamberlain JF, Miller SA, Frederick JR (2011) Using DAYCENT to quantify on-farm GHG emissions and $\mathrm{N}$ dynamics of land use conversion to $\mathrm{N}$-managed switchgrass in the southern U.S. Agric Ecosyst Environ $141: 332-341$

37. Fazio S, Monti A (2011) Life cycle assessment of different bioenergy production systems including perennial and annual crops. Biomass Bioenergy 35:4868-4878

38. IPCC (2006) $\mathrm{N}_{2} \mathrm{O}$ emissions from managed soils, and $\mathrm{CO}_{2}$ emissions from lime and urea application. In: Eggleston HS, Buendia L, Miwa K, Ngara T, Tanabe K (eds) Guidelines for national greenhouse gas inventories, prepared by the National Greenhouse Gas Inventories Programme, vol 4, 11th edn. IGES, Hayama, Japan

39. Qin X, Mohan T, El-Halwagi M, Cornforth G, McCarl BA (2006) Switchgrass as an alternate feedstock for power generation: an integrated environmental, energy and economic life-cycle assessment. Clean Techn Environ Policy 8:233-249

40. Adler PR, Del Grosso SJ, Parton WJ (2007) Life-cycle assessment of net greenhouse-gas flux for bioenergy cropping systems. Ecol Appl 17:675-691

41. Crutzen PJ, Mosier AR, Smith KA, Winiwarter W (2008) $\mathrm{N}_{2} \mathrm{O}$ release from agro-biofuel production negates global warming reduction by replacing fossil fuels. Atmos Chem Phys 8:389-395

42. Peichl M, Leava NA, Kiely G (2012) Above- and belowground ecosystem biomass, carbon and nitrogen allocation in recently afforested grassland and adjacent intensively managed grassland. Plant Soil 350:281-296

43. Polglase PJ, Paul KI, Khanna PK, Nyakuengama JG, O'Connell AM, Grove TS, Battaglia M (2000) Change in soil carbon following afforestation or reforestation: review of experimental evidence and development of a conceptual framework. In: NCAS technical report No. 20. Australian Greenhouse Office, Canberra, p 117

44. Monti A, Zatta A (2009) Root distribution and soil moisture retrieval 
in perennial and annual energy crops in northern Italy. Agric Ecosyst Environ 132:252-259 